\title{
STUDI ANTESEDEN INTERNAL DAN EKSTERNAL KINERJA PEGAWAI PERANGKAT DESA
}

\author{
Heri Purwanto ${ }^{1}$, Siska Agustina Dewi ${ }^{2}$, M. Trihudiatmanto ${ }^{3}$, M. Elfan Kaukab ${ }^{4}$ \\ ${ }^{1,2,3,4}$ Fakultas Ekonomi dan Bisnis, Universitas Sains Al-Qur'an Wonosobo \\ Corresponding author : heripurwanto@unsiq.ac.id
}

\begin{abstract}
ABSTRAK
Tujuan dari penelitian ini adalah untuk menganalisis pengaruh disiplin kerja, motivasi kerja (internal), dan lingkungan kerja (eksternal) terhadap kinerja pegawai perangkat desa. Data yang digunakan dalam penelitian ini adalah data primer berdasarkan kuesioner yang dibagikan kepada sebagian perangkat desa di Kecamatan Punggelan. Sampel yang digunakan 200 responden sebagai batas minimial kecukupan untuk alat analisis yang digunakan yaitu Structural Equation Model (SEM). Hasil penelitian ini menujukan bahwa disiplin kerja, motivasi kerja, dan lingkungan kerja berpengaruh positif terhadap kinerja pegawai perangkat desa di Kecamatan Punggelan Kabupaten Banjarnegara.
\end{abstract}

Kata kunci: Disiplin kerja, motivasi kerja, lingkungan kerja, kinerja pegawai.

\section{PENDAHULUAN}

Diera modern seperti ini sumber daya manusia sangat dibutuhkan oleh suatu organisasi atau perusahaan. Pegawai yang mempunyai kinerja yang baik merupakan sumberdaya manusia yang dibutuhkan oleh sebuah organisasi maupun perusahaan demi mencapai tujuan suatu organisasi. Oleh karena itu suatu organisasi ataupun prusahaan harus mengapresiasi para pegawai yang memiliki kualitas kinerja tinggi (Bruce, 2003). Keberhasilan suatu organisasi tidak hanya dilihat dari output yang telah dikeluarkan dan hasil yang didapatkan tetapi lebih kepada output, proses, manfaat didapatkan dan akibat dari organisasi tersebut bagi kesejahteraan masyarakat (Ngakil dan Kaukab, 2020). Kinerja yang baik dapat dilihat dari bagaimana cara suatu organisasi atau perusahaan mengelola sumber dayanya dalam memperoleh hasil dari tujuan yang telah direncanakan (Waryanti, 2011).

Kinerja (performance) adalah tingkat dari suatu pencapaian visi misi dan tujuan dari suatu organisasi. Kinerja biasanya disebut juga sebagai kesuksesan individu atau organisasi (Mahsun, Firma, dan Heribertus, 2007). Kinerja pegawai dapat diukur dari indikator kesesuaian dalam menyelesaikan tugas, ketepatan waktu dalam bekerja, kehadiran atau presensi dan cara bekerja sesama dengan pegawai (Setiawan dan Kartika, 2014). Indikator pengukuran kinerja pegawai belum sepenuhnya dapat terlaksanakan di Balai Desa Kecamatan Punggelan Kabupaten Banjarnegara. Kinerja perangkat desa di Kecamatan Punggelan mengikuti acuan sesuai dengan Peraturan Pemerintah No. 10 tahun 1979 tentang penilaian kerja pegawai dengan unsur penilaian kesetiaan, prestasi kerja, tanggung jawab, ketaatan, kejujuran, kerjasama, prakarsa, dan kepemimpinan. 
Tabel 1

Rekapitulasi rata-rata hasil penilaian kinerja pegawai perangkat desa di Kecamatan Punggelan (2018-2019)

\begin{tabular}{clcccc}
\hline \multirow{2}{*}{ No } & \multirow{2}{*}{ Unsur } & \multicolumn{2}{c}{ Tahun 2018 } & \multicolumn{2}{c}{ Tahun 2019 } \\
\cline { 3 - 6 } & & Nilai & Keterangan & Nilai & Keterangan \\
\hline 1 & Kesetiaan & 91 & Amat Baik & 72 & Cukup \\
2 & Prestasi Kerja & 85 & Baik & 75 & Cukup \\
3 & Tanggung Jawab & 80 & Baik & 80 & Baik \\
4 & Ketaatan & 82 & Baik & 78 & Baik \\
5 & Kejujuran & 82 & Baik & 73 & Cukup \\
6 & Kerjasama & 80 & Baik & 70 & Cukup \\
7 & Prakarsa & 80 & Baik & 75 & Cukup \\
8 & Kepemimpinan & 88 & Baik & 80 & Baik \\
\hline \multicolumn{7}{c}{ Jumlah } & 668 & & 603 & \\
\hline \multicolumn{7}{c}{ Rata-Rata } & 83,5 & Baik & 75,375 & Cukup
\end{tabular}

Sumber: Data sekunder yang diolah, tahun 2020

Pada Tabel 1 dapat dilihat bahwa rata-rata kinerja pegawai pada Perangkat Desa di Kecamatan Punggelan pada tahun 2018 sudah baik akan tetapi pada tahun 2019 kinerja pegawai mengalami penurunan sebesar $8,125 \%$ terlihat pada unsur Kesetiaan, Prestasi Kerja, Kejujuran, Kerjasama dan Prakarsa yang cukup signifikan, sehingga terindikasi bahwa pada tahun 2019 terdapat masalah pada kinerja pegawai.

Dalam pelaksanaan sebuah kegiatan pasti menginginkan kinerja yang maksimal sesuai dengan standar yang diterapkan oleh setiap tempat kerja agar dapat terwujud kinerja yang diinginkan, banyak faktor yang mempengaruhi kinerja bagi pegawai. Menurut Hasil Penelitian Syafrina (2017) dengan judul Pengaruh disiplin kerja terhadap kinerja pegawai salah satu faktor yang mempengaruhi kinerja adalah disiplin kerja. Kinerja pegawai yang bagus adalah yang dapat menerapkan disiplin kerja di instansi maupun oganisasi salah satu cotohnya adalah menaati dan mematuhi peraturan yang ada disuatu instansi, perusahaan, maupun organisasi. Disiplin merupakan salah satu tolak ukur baik atau tidaknya suatu kinerja karena jika kedisiplinan itu tidak diterapkan dengan baik disuatu instansi ataupun perusahaan maka dalam pencapaian tujuan menjadi tidak maksimal.

Hal tersebut juga diperkuat lagi dengan penelitian Setiawan (2013) menunjukkan bahwa variabel disiplin kerja memiliki pengaruh positif dan signifikan terhadap kinerja karyawan (Studi pada Rumah Sakit Umum Daerah Kenjuran Malang). Hasibuan (2006) menjabarkan tentang disiplin kerja adalah suatu bentuk dimana seseorang harus menaati peraturan yang diberikan baik itu instansi, perusahaan maupun organisasi. Namun yang terjadi, pihak instansi kurang tegas kepada perangkat yang melanggar peraturan, sehingga para perangkat desa di Kecamatan Punggelan dalam melakukan pekerjaanya tidak sesuai dengan peraturan yang telah ditetapkan, bahkan tidak memikirkan sanksi yang akan mereka terima apabila melanggar peraturan yang telah diterapkan sehingga kedisiplinan yang ada masih sangat rendah (Setyowati, 2016).

Selain disiplin kerja, motivasi kerja juga sangat penting untuk meningkatkan kinerja. Menurut penelitian Gardjito dkk (2015) dengan judul pengaruh motivasi kerja 
dan lingkungan kerja terhadap kinerja karyawan adalah pemberian motivasi dan kenyamanan lingkungan kerja. Pekerja dapat bekerja makin produktif apabila mendapat motivasi dari luar maupun dalam suatu instansi (organisasi). Dengan produktivitas kerja yang tinggi, ongkos pegawai akan semakin rendah (Hayati et al, 2020).

Hal tersebut juga diperkuat oleh penelitian Potu (2013) menunjukan bahwa variabel motivasi kerja memiliki pengaruh positif terhadap kinerja karyawan (Studi pada Kanwil Ditjen Negara Suluttenggoro dan Maluku Utara di Manado). Menurut Sondang P Siagian (2008) motivasi adalah daya pendorong yang mengakibatkan seseorang rela dan ikhlas melakukan tanggungjawab dengan tugas yang telah diberikan dalam rangka pencapian tujuan yang telah direncanakan oleh instansi, perusahaan maupun organisasi. Dengan adanya motivasi maka pegawai akan melakukan tindakan yang bertujuan agar berprestasi dan memperoleh jabatan yang lebih tinggi, hal tersebut dapat dilihat pengaruh motivasi terhadap kinerja (Kaukab et al. 2020)

Lingkungan kerja yang baik yaitu lingkungan kerja yang mampu memeberikan rasa aman, nyaman kepada para pegawai sehingga mereka dapat merasa senang dan tenang dalam menjalankan tugasnya (Sidanti, 2015). Menurut penelitian Gardjito, H dkk (2015) dengan judul Pengaruh Motivasi Kerja dan Lingkungan Kerja terhadap kinerja karyawan. Lingkungan kerja yang nyaman bagi pegawainya dapat meningkatkan kinerja adalah Pemberian motivasi dan kenyamanan lingkungan kerja. Lingkungan kerja yang tidak memadai akan dapat menurunkan kinerja dan akhirnya menurunkan motivasi kerja pegawai. Lingkungan kerja yang baik akan menjadikan pekerja menjadi lebih berkembang, inovatif dan kreatif sehingga dapat menghasilakan kinerja dengan produktifitas tinggi.

Penelitian Gardjito (2014) juga memperkuat penelitan dari Rozalina (2015) yang menunjukkan bahwa variabel Lingkungan Kerja memiliki pengaruh positif dan signifikan terhadap kinerja karyawan (Studi pada Karyawan Bagian Produksi PT Mitra Andalan Surabaya). Lingkungan kerja adalah tempat dimana karyawan melakukan aktivitas setiap harinya. Lingkungan kerja yang baik apabila pegawai dapat melaksanakan kegiatan secara maksimal, aman dan nyaman. Supardi (2003) menyatakan lingkungan kerja merupakan keadaan sekitar tempat kerja baik, dapat memberikan kesan menyenangkan, mengamankan, menentramkan dan kesan betah bekerja dan lain sebagainya. Lingkungan kerja merupakan hal yang berpengaruh penting terhadap baik buruknya kualitas hasil kinerja pegawai. Bila lingkungan kerja nyaman dan komunikasi antar pegawai berjalan lancar, maka hasil kinerjanya akan maksimal. Sedangkan tidak jarang di desa-desa yang terdapat di Kecamatan Punggelan tidak menyediakan fasilitas-fasilitas lengkap, dan lingkungan kerja mereka berada dilingkungan yang tidak harmonis dan tidak nyaman sehingga sangat mempengaruhi kinerja mereka dan keamanan di lingkungan kerja mereka kurang terjaga dengan baik dan hasil kinerjanya menjadi tidak maksimal, seperti halnya tidak jarang perangkat desa menggunakan dana desa untuk kepentingannya sendiri (Sofyan, 2016).

Penelitian ini mengembangkan dari penelitian terdahulu oleh Setiawan (2013) dengan judul pengaruh Disiplin kerja dan Motivasi kerja terhadap Kinerja Karyawan pada RSUD Kanjuruhan Malangdengan menambahkan satu variabel lingkungan kerja. Penambahan variabel lingkungan kerja juga berdasarkan dari penelitian Potu, A (2013), Suhartini (2016), Munpadi (2012), Syafrina (2017), Gardjito (2014), Rozalina (2015) yang menyatakan bahwa lingkungan kerja berpengaruh positif tehadap kinerja pegawai. Hal tersebut juga diperkuat oleh Barry Render \& Jay Heizer (2011) yang mengatakan bahwa lingkungan kerja fisik tempat karyawan bekerja yang memepengaruhi kinerja, 
keamanan dan kenyamanan dalam bekerja .Dan dalam penelitian yang dilakukan Setiawan (2013) terdapat kekuranganyaitu tidak berpengaruhnya kedisiplinan terhadap kinerja karyawan sedangkan menurut Desslerr (2000) ada lima faktor penilaian kerja yaitu prestasi kerja, kuantitas pekerjaan, kepemimpinan yang diperlukan, kedisiplinan dan personal quality sehingga peneliti ingin membuktikan kebenarannya apakah kedisiplinan berpengaruh positif terhadap kinerja atau tidak berpengaruh.

\section{LANDASAN TEORI DAN PENGEMBANGAN HIPOTESIS}

Disiplin Kerja adalah sebagai suatu sikap menghormati, menghargai, patuh dan taat terhadap peraturan-peraturan yang berlaku, baik tertulis maupun tidak tertulis serta sanggup menjalankannya dan tidak mengelak untuk menerima sanksi-sanksinya apabila ia melanggar tugas dan wewenang yang diberikan kepadanya (Mangkunegara, 2007). Dalam penelitian yang dilakukan oleh Suhartini pada tahun 2016 yang berjudul pengaruh disiplin kerja dan lingkungan kerja terhadap kinerja guru studi pada guru di SD swasta sultan agung di pemantangsiantar, yang menujukan bahwa variabel Disiplin kerja berpengaruh positif terhadap Kinerja Karyawan. Penelitian dari Syafrina, N pada tahun 2017 yang berjudul Pengaruh Disiplin Kerja terhadap Kinerja Karyawan studi pada PT. Suka Fajar Pekanbaru juga menujukan hasil bahwa disiplin kerja berpengaruh positif terhadap kinerja karyawan. Dan diperkuat dengan penelitian yang dilakukan oleh Sidanti, H pada tahun 2015 yang berjudul Pengaruh Lingkungan kerja, Disiplin kerja dan Motivasi kerja terhadap Kinerja pegawai studi pada PNS DPRD kabupaten Madiun menujukan hasil bahwa disiplin kerja berpengaruh positif terhadap kinerja karyawan. Dengan demikian dapat diartikan baha disiplin keja seperti taat terhadap aturan waktu, taat terhadap aturan dalam bekerja, taat terhadap peraturan instansi, taat terhadap peraturan lainnya berpengaruh terhadap kinrja pegawai pada perangkat desa dikecamatan punggelan. Hal ini menjelaskan bahwa disiplin kerja merrupakan salah satu variabel penting dari kinerja pegawai khususnya kinerja pada perangkat desa dikecamatan punggelan.

$H_{1}$ : Disiplin Kerja berpengaruh positif terhadap kinerja Perangkat Desa di Kecamatan Punggelan.

Motivasi kerja adalah upaya-upaya yang memunculkan semangat dari dalam orang itu sendiri melalui fasilitas penyedia kepuasan Kusnadi (2002). Dalam penelitian yang dilakukan oleh Setiawan pada tahun 2013 yang berjudul Pengaruh Disiplin Kerja dan Motivasi Kerja terhadap Kinerja Karyawan Studi kasus pada RSUD Kanjuruhan Malang menujukan hasil bahwa Motivasi kerja berpengaruh positif terhadap kinerja karyawan. Penelitian yang dilakukan oleh Potu (2013) yang berjudul Kepemimpinan, Motivasi dan lingkungan kerja pengaruhnya terhadap kinerja karyawan studi pada kanwil ditjen kekayaan negara sulutteggo dan maluku utara di manado menujukan hasil bahwa Motivasi kerja berpengaruh positif terhadap kinerja karyawan. Penelitian yang dilakukan oleh Sidanti (2015) yang berjudul Pengaruh Lingkungan kerja, Disiplin kerja dan Motivasi kerja terhadap Kinerja pegawai studi pada PNS DPRD kabupaten Madiun juga menujukan hasil bahwa Motivasi kerja berpengaruh positif terhadap kinerja karyawan. Dan diperkuat oleh penelitian yang dilakukan oleh Setiawan, A pada tahun 2013 yang berjudul Pengaruh Disiplin Kerja dan Motivasi Kerja terhadap Kinerja Karyawan Studi kasus pada RSUD Kanjuruhan Malang yang menujukan hasil bahwa Motivasi kerja berpengaruh positif terhadap kinerja karyawan yang menujukan hasil bahwa Motivasi kerja berpengaruh positif terhadap kinerja karyawan. Dengan demikian dapat diartikan bahwa motivasi kerja seperti daya pendorong, kemauan, kerelaan, membentuk keahlian, 
membentuk ketrampilan, tanggungjawab, kewajiban, dan tujuanberpengaruh terhadap kinerja pegawai pada perangkat desa dikecamatan punggelan. Hal ini menjelaskan bahwa disiplin kerja merrupakan salah satu variabel penting dari kinerja pegawai khususnya kinerja pada perangkat desa dikecamatan punggelan sebagai lembaga pemeritahan tetap mengutamakan mutu kinerja pegawainya salah satunya dengan peningkatan motivasi kerja hal demikian menejelaskan bahwa motivasi kerja terdapat hubungan erat denga kinerja pegawai.

$\mathrm{H}_{2}$ : Motivasi Kerja berpengaruh positif terhadap kinerja Perangkat Desa di Kecamatan Punggelan

Lingkungan kerja merupakan suatu sarana atau tempat yang sangat berperan dalam suatu organisasi. Keadaan tempat bekerja seseorang karyawan dapat mempengaruhi karyawan dalam menjalankan aktivitas dan tugas yang dibebankan (Artana, 2013). Dalam penelitian yang dilakukan Munparidi pada tahun 2012 yang berjudul pengaruh kepemimpinan, motivasi, pelatihan dan lingkungan kerja terhadap kinerja karyawan studi pada perusahaan daerah air minum tirta musi kota palembang menujukan hasil bahwa Lingkungan kerja berpengaruh positif terhadap kinerja karyawan. Penelitian yang dilakukan oleh Gardijto (2014) yang berjudul Pengaruh Motivasi Kerja dan Lingkungan Kerja terhadap kinerja karyawan studi pada karyawan PT. Karmand Mitra Andalan bagian Produksi juga menujukan hasil bahwa Lingkungan kerja berpengaruh positif terhadap kinerja karyawan. Dan diperkuat oleh penelitian yang dilakukan oleh Rozalina (2015) yang berjudul pengaruh Motivasi Kerja dan Disiplin Kerja terhadap Kinerja Karyawan studi pada Karyawan PT. Pattindo Malang menujukan hasil bahwa Lingkungan kerja berpengaruh positif terhadap kinerja karyawan. Dengan demikian dapat diartikan bahwa lingkungan kerja seperti penerangan, temperatur, tata warna, keamanan, bau tak sedap, musik dekorasi, dan kebisingan berpengaruh terhadap kinerja pegawai pada perangkat desa dikecamatan punggelan. Hal ini menjelaskan bahwa disiplin kerja merrupakan salah satu variabel penting dari kinerja pegawai khususnya kinerja pada perangkat desa dikecamatan punggelan sebagai lembaga pemeritahan tetap mengutamakan lingkungan kerja yang aman nyaman dan sehat bagi para pegawainya dengan demikian dapat disimpulkan bahwa lingkungan kerja mempunyai hubungan erat dengan kinerja pegawai pada perangkat desa dikecamatan punggelan.

$H_{3}$ : Motivasi Kerja berpengaruh positif terhadap kinerja Perangkat Desa di Kecamatan Punggelan.

\section{MODEL PENELITIAN}

Setelah dilakukan telaah pustaka yang mendasari perumusan masalah yang diajukan dalam penelitian ini, selanjutnya dibentuk kerangka pemikiran teoritis yang

akan digunakan sebagai acuan untuk pemecahan masalah. Kerangka pemikiran teoritis yang dibangun ditampilkan dalam gambar sebagai berikut: 


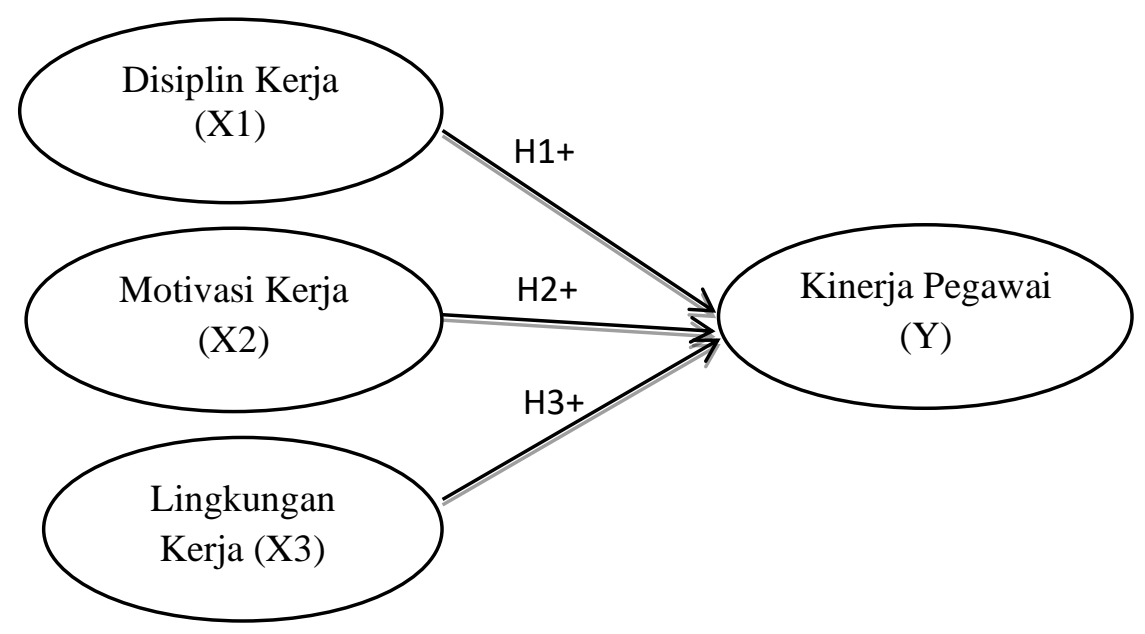

Gambar 1. Kerangka Pikir Penelitian

\section{METODE PENELITIAN}

Penelitian ini termasuk penelitian survey. Dalam penelitian ini populasi seluruh pegawai perangat desa di Kecamatan Punggelan adalah 185 orang. Pada penelitian ini jumlah indikatornya sebesar 24 indikator (item pertanyaan) dan menggunakan metode estimasi maxsimum likehood maka dengan rule of thumb, ukuran sampel yang diperlukan minimal 24 X $5=120$ responden. Model yang akan digunakan dalam penelitian ini adalah model kausalitas atau hubungan atau pengaruh untuk menguji hipotesis yang diajukan, maka teknik analisis yang digunakan adalah SEM (Structural Equation Method).

Definisi operasional variabel setiap variabel dengan beberapa indicator. Kinerja pegawai menurut Prawirosentono (1999) yang dibentuk dari 4 indikator yaitu efektifitas dan efisiensi, otoritas (wewenang), disiplin, dan inisiatif. Indikator dalam variabel disiplin kerja menurut Sutrisno (2009) ada 4 yaitu taat terhadap aturan waktu, taat terhadap peraturan instansi, taat terhadap aturan perilaku dalam pekerjaan, dan taat terhadap peraturan lainnya diinstansi. Indikator Motivasi kerja menurut Sondang $\mathrm{P}$ siagian (2008) terdiri dari 8 yaitu daya pendorong, kemauan, kerelaan, membentuk keahlian, membentuk keterampilan, tanggung jawab, kewajiban, dan tujuan. Indikator lingkungan kerja menurut Sedarmayanti (2009) ada 8 yaitu penerangan atau cahaya ditempat kerja, temperatur atau suhu udara ditempat kerja, tata warna ditempat kerja, keamanan ditempat kerja, bau tak sedap ditempat kerja, musik ditempat kerja, dekorasi ditempat kerja, dan kebisingan ditempat kerja. 


\section{HASIL DAN PEMBAHASAN}

Output Full Model SEM dalam penelitian ini selengkapnya adalah sebagai berikut:

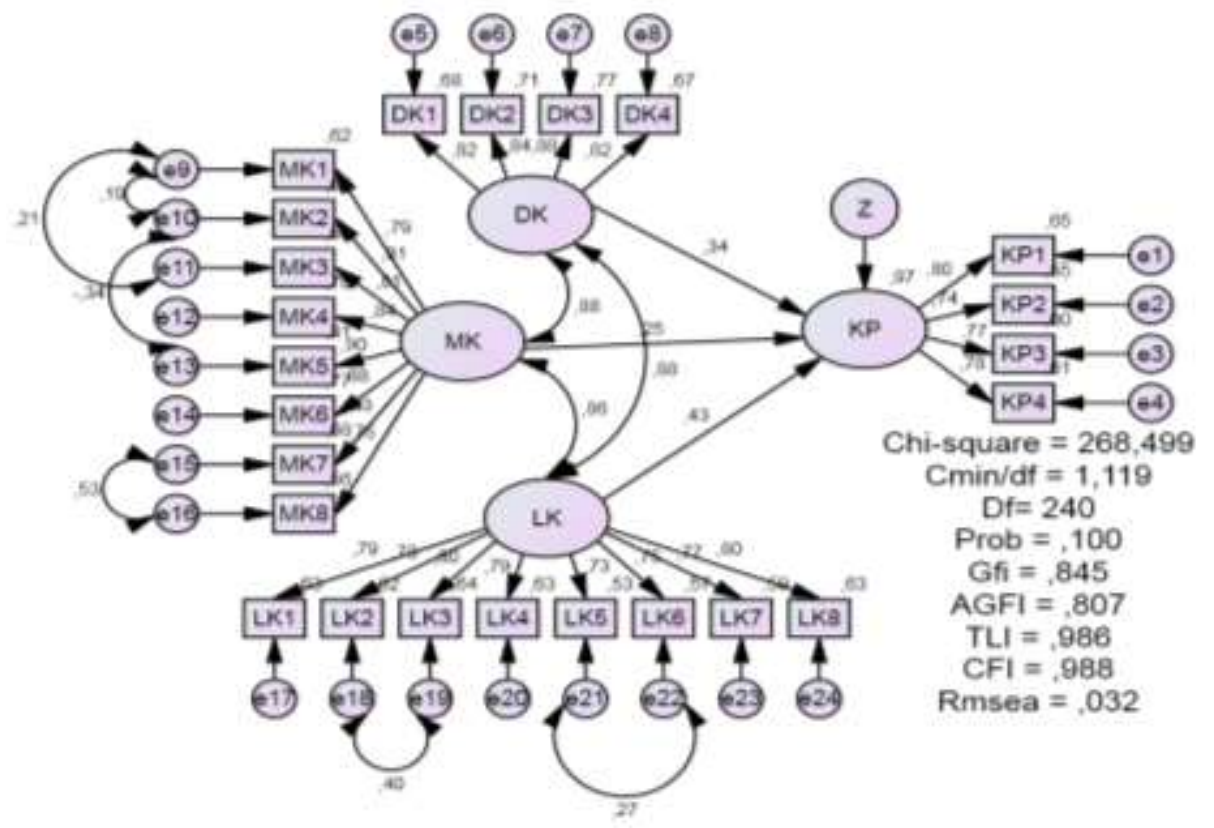

Gambar 2. Model Analisis Goodness of Fit

Tampak bahwa uji yang ada telah memenuhi syarat yang ditentukan atau mendekati dengan nilai yang disarankan, dalam hal ini adalah GFI dan AGFI jika $\leq 0,08$ / $\leq$ 0,90 masuk kategori marjinal. Dengan demikian, dinyatakan bahwa model telah dinyatakan fit untuk dianalisis (Wijanto, 2008).

\section{Tabel 2}

Output Full Model Goodness of Fit

\begin{tabular}{llll}
\hline \multicolumn{1}{c}{ Goodness of fit index } & \multicolumn{1}{c}{ Cut-off Value } & Estimasi & Keterangan \\
\hline Chi-square $\left(\chi^{2}\right)$ & Diharapkan kecil & 268,499 & Baik \\
Significance probability & $\geq 0,05$ & 0,100 & Baik \\
RMSEA & $\leq 0,08$ & 0,032 & Baik \\
GFI & $\geq 0,90$ & 0,845 & Marjinal \\
AGFI & $\geq 0,90$ & 0,807 & Marjinal \\
CMIN/DF & $\leq 3,00$ & 1,119 & Baik \\
TLI & $\geq 0,95$ & 0,986 & Baik \\
CFI & $\geq 0,95$ & 0,988 & Baik \\
\hline
\end{tabular}

Sumber : Data primer yang diolah, tahun 2020

Setelah model dinyatakan fit, kemudian dilakukan uji normalitas dengan hasil uji diatas Nilai CR bernilai 1, 083 berarti sesuai dengan kriteria yaitu dibawah 2,58 maka data tersebut dikatakan normal. Hasil perhitungan nilai variance inflation factor (VIF) juga menunjukkan hal yangsama, dimana tidak ada satu variabel bebas yang memiliki nilai VIF lebih dari 10.Jadi dapat disimpulkan bahwa tidak ada multikolinearitas antar variabelindependen dalam model regresi. Untuk Reliability Construct, nilainya sudah 
diatas 0,7 untuk semua konstruk. Hasil ini menunjukkan bahwa rangkaian kuesioner yang dipergunakan untuk mengukur variabel penelitian sudah valid dan reliabel.

Tabel 3

Hasil Pengujian Hipotesis

\begin{tabular}{lllllll}
\hline & & Estimate & S.E. & C.R. & P & Label \\
\hline KP <--- & DK &, 322 &, 137 & 2,348 &, 019 & par_24 \\
KP <--- & LK &, 415 &, 128 & 3,243 &, 001 & par_25 \\
KP <--- & MK &, 226 &, 111 & 2,041 &, 041 & par_26 \\
\hline
\end{tabular}

Sumber : Data primer yang diolah, tahun 2020

Berdasarkan hasil output diatas diperoleh hasil pengujian hipotesis sebagai berikut:

$\mathrm{H}_{1}$ : Disiplin kerja berpengaruh positif terhadap kinerja pegawai pada perangkat desa di kecamatan punggelan. Berdasarkan data hasil pengolahan data dapat diketahui bahwa nilai $\mathrm{P}$ (probability) $0,19<0,05$. Nilai ini menunjukkan hasil yang memenuhi syarat dari ketentuan untuk $\mathrm{P}(0,05)$ maka $\mathrm{H} 1$ dalam penelitian ini diterima.

H2 : Motivasi Kerja berpengaruh positif terhadap kinerja pegawai pada perangkat desa di kecamatan punggelan. Berdasarkan data hasil pengolahan data dapat diketahui bahwa nilai $\mathrm{P}$ (probability) 0,001 < 0,05. Nilai ini menunjukkan hasil yang memenuhi syarat dari ketentuan untuk $\mathrm{P}(0,05)$ maka $\mathrm{H} 2$ dalam penelitian ini diterima.

H3: Lingkungan kerja berpengaruh positif terhadap kinerja pegawai pada perrangkat desa di kecamaan punggelan. Berdasarkan data hasil pengolahan data dapat diketahui bahwa nilai P (probability) $0,041<0,05$. Nilai ini menunjukkan hasil yang memenuhi syarat dari ketentuan untuk $\mathrm{P}(0,05)$ maka $\mathrm{H} 3$ dalam penelitian ini diterima.

Koefisien determinasi pada intinya mengukur seberapa jauh kemampuan model menerangkan variasi independen ke variabel dependen (Ghozali, 2016). Hasil besarnya pengaruh koefisien determinasi $\left(\mathrm{R}^{2)}\right.$ atau sebesar 0,972 atau 97,2\% maka dapat dijelaskan bahwa 97,2\% Kinerja Pegawai dipengaruhi oleh faktor Disiplin kerja, Motivasi kerja dan Lingkungan kerja sedangkan 2,8\% dipengaruhi oleh variabel lain.

Berdasarkan penelitian diperoleh hasil bahwa disiplin kerjaberpengaruh positf terhadap kinerja pegawai pada perangkat desa dikecamtan punggelan, hal ini dapat menujukan bahwa semakin tinggi tingkat disiplinnya maka akan semakin maksimal kinerjanya. Hasil penelitian ini konsisten dengan penelitaian yang dilakukan oleh suhartini (2016) yang menyatakan bahwa disiplin kerja berpengaruh positif terhadap kierja pegawai, hasil ini juga konsisiten dengan penelitian terdahulu yang dilakukan oleh Sidanti (2015) dan Syafrina (2017) yang menujukan bahwa didiplin kerja berpengaruh positif terhadap kinerja pegawai. Dapat dilihat juga dari hasil penelitian diatas menujukan estimasi untuk pengujian pengaruh disiplin kerja terhadap Kinerja pegawai menunjukkan nilai CR sebesar 2, 348 dan dengan probabilitas sebesar 0,019. Kedua nilai tersebut diperoleh memenuhi syarat untuk penerimaan $\mathrm{H} 1$ yaitu nilai CR sebesar 2,348 yang lebih besar dari 1,96 dan probabilitas yang lebih kecil dari 0,05. Dengan demikian dapat disimpulkan bahwa disiplin kerja berpengaruh positif terhadap kinerja pegawai pada perangkat desa di kecamatan punggelan yang artinya apabila disiplin kerja baik maka kinerja yang dilakukan akan menjadi maksimal dan begitupula sebaliknya. Lurah 
atau kepala desa harusnya lebih memperhatikan disiplin kerjanya agar kinerja perangkatnya menjadi lebih maksimal dan citra kinerja perangkat desa dimata masyaratakan baik dan mereka puas dengan pelayanan kinerja yang dibeikan.

Berdasarkan penelitian diperoleh hasil bahwa motivasi kerja berpengaruh positif terhadap kinerja pegawai pada perangkat desa dikecamtan punggelan, hal ini dapat menujukan bahwa semakin tinggi tingkat motivasi kerja yang diberikan maka akan semakin maksimal kinerjanya. Hasil penelitian ini konsisten dengan penelitaian yang dilakukan oleh Setiawan (2013), Potu (2013), Sidanti (2015) Gadjito (2014) dan Rozalina (2015) yang menujukan bahwa motviasi kerja berpengaruh positif terhadap kinerja pegawai. Dapat dilihat juga dari hasil penelitian diatas menujukan estimasi untuk pengujian pengaruh Motivasi kerja terhadap Kinerja pegawai menunjukkan nilai CR sebesar 3,243 dan dengan probabilitas sebesar 0,001. Kedua nilai tersebut diperoleh memenuhi syarat untuk penerimaan $\mathrm{H} 2$ yaitu nilai CR sebesar 3,243 yang lebih besar dari 1,96 dan probabilitas yang lebih kecil dari 0,05. Dengan demikian dapat disimpulkan bahwa motivasi kerja berpengaruh positif terhadap kinerja pegawai pada perangkat desa di kecamatan punggelan yang artinya apabila motivasi kerja baik maka kinerja yang dilakukan akan menjadi maksimal dan begitupula sebaliknya. Dalam hal ini berarti pimpinan desa harus lebih memperhatikan motivasi karna hal tersebut sangat berpengaruh terhadap kinerja perangkat dengan adanya motivasi yang diberikan seperti pemberian insentif, bonus maka mereka akan meningkatkan kinerjanya dan citra dalam melayani masyarakat menjadi lebih maksimal.

Berdasarkan penelitian diperoleh hasil bahwa Lingkungan kerja berpengaruh positif terhadap kinerja pegawai pada perangkat desa dikecamtan punggelan, hal ini dapat menujukan bahwa semakin baik kondisi lingkungan maka akan semakin maksimal kinerjanya. Hasil penelitian ini konsisten dengan penelitaian yang dilakukan oleh Potu (2013), Suhartini (2016), Munparidi (2012), Gardjito (2014), dan Rozalina (2015) yang menujukan bahwa Lingkungan kerja berpengaruh positif terhadap kinerja pegawai. Dapat dilihat dari hasil penelitian diatas menujukan estimasi untuk pengujianpengaruh disiplin kerja terhadap Kinerja karyawan menunjukkan nilai CR sebesar 2, 348 dan dengan probabilitas sebesar 0,041. Kedua nilai tersebut diperoleh memenuhi syarat untuk penerimaan $\mathrm{H} 3$ yaitu nilai CR sebesar 2,041 yang lebih besar dari 1,96 dan probabilitas yang lebih kecil dari 0,05. Dengan demikian dapat disimpulkan bahwa lingkungan kerja berpengaruh positif terhadap kinerja pegawai pada perangkat desa di kecamatan punggelan yang artinya apabila lingkungan kerja baik maka kinerja yang dilakukan akan menjadi maksimal dan begitupula sebaliknya. Perangkat harus lebih meningkatkan kondisi lingkungan kerja para pegawainya salah satunya dengan mengedepankan keamanan kenyamnan dan kebersihan lingkunga kerja agar pegawai dalam menjalakan tugasnya dapat berjalan secara maksimal.

\section{PENUTUP}

\section{Kesimpulan}

Pengujian hipotesis yang dilakukan membuktikan bahwa ada pengaruh yang searah antara Disiplin Kerja dengan Kinerja Pegawai. Hal tersebut menujukan semakin disiplin dalam bekerja maka akan membuat kinerja menjadi lebih baik. Pengujian hipotesis yang dilakukan membuktikan bahwa ada pengaruh yang searah antara Motivasi Kerja dengan Kinerja Pegawai. Hal tersebut menujukan semakin tinggi motivasi dalam bekerja maka kinerja yang dihasilkan akan semakin baik. Pengujian hipotesis yang dilakukan membuktikan bahwa ada pengaruh yang searah antara Lingkungan Kerja 
dengan Kinerja Pegawai. Hal tersebut menujukan semakin Lingkungan dalam bekerjanya nyaman, aman maka kinerjanya akan menjadi baik.

\section{DAFTAR PUSTAKA}

Agusta, S, R. 2014. Analisis Pengaruh Gaya kepemimpinan Transformasional, kepuasan Kompensasi, dan Komitmen Organisasional Terhadap Kinerja Karyawan (Studi Pada Kantor Mpc Pt. Pos Indonesia Cabang Semarang). Skripsi. Semarang: Fakultas Ekonomika Dan Bisnis Universitas Diponegoro Semarang. (Skripsi Tidak dipublikasikan).

Arida, A. 2010. Jurnal : Pengaruh Motivasi, Lingkungan Kerja dan Kepemimpinan Terhadap Kinerja Karyawan. PT. SAI Apparel Semarang.

Bacal dan Robert (2012). Performance Management Terjemahan Surya Dharma dan Yanuar Irawan. Penerbit Gramedia Pustaka

Bachrudin, A., \& Harapan L. T. (2003). Analisis Data Untuk Penelitian Survai dengan Menggunakan Lisrel 8. Bandung: Jurusan Statistika FMIPA - Unpad

Basuki dan Susilowati. 2005. Dampak Kepemimpinan dan Lingkungan Kerja terhadap Semangat Kerja. Jurnal JRBI, Vol. 1, No. 1, Januari.

Bruce, A. 2003. Rahasia Tempat Kerja: Penuh Semangat dan Menyenangkan. Jakarta: Serambil Ilmu Semesta.

Cahyono, B dan Suharto, 2005, pengaruh Budaya Organisasi, Kepemimpinan dan Motivasi Kerja Terhadap Kinerja Sumber Daya Manusia Di Sekretariat DPRD Propinsi Jawa Tengah. Jurnal. Yogyakarta: JRBI Vol. 1.

Dessler, G. 2000. Human Resource Management. 8th edition. New Jersey: Prentice-Hall, Inc.

Eka, S.N. 2015. Pengaruh kepemimpinan, fasilitas kerja dan motivasi kerja terhadap kinerja perangkat desa di kecamatan mandiraja kabupaten banjarnegara.Jurusan pendidikan ekonomi, fakultas ekonomi, Universitas Negri Semarang.

Ferdinand, A. 2014. Metode Penelitian Manajemen. BP Universitas Diponegoro Semarang.

Gardjito, A, dkk. 2015. Pengaruh Motivasi Kerja dan Lingkungan Kerja terhadap kinerja karyawan studi pada karyawan PT. Karmand Mitra Andalan bagian Produksi. Fakultas Ilmu Administrasi Universitas Brawijaya Malang

Ghozali, I. 2011. Aplikasi Analisis Multivariate Dengan Program SPSS. Semarang: Badan Penerbit Universitas Diponegoro Semarang.

Ghozali, I. 2011. Model Persamaan Struktural Konsep dan Aplikasi dengan Program AMOS 19. Semarang: Badan Penerbit Universitas Diponegoro.

Ghozali, I dan Latan, H. 2015. Konsep, Teknik, Aplikasi Menggunakan Smart PLS 3.0 Untuk Penelitian Empiris. BP Undip. Semarang

Ghozali, I. 2016. Aplikasi Analisis Multivariete Dengan Program IBM SPSS 23 (Edisi 8). Cetakan ke VIII. Semarang : Badan Penerbit Universitas Diponegoro.

Hair, Jr , Anderson, R. E, Tatham, R. L, \& Black, W. C. 2006. Multivariate Data Analysis. 6th Edition, New Jersey: Prentice-Hall International, Inc.

Hartono, J. 2007. Metodologi Penelitian Bisnis: Salah Kaprah dan PengalamanPengalaman. Yogyakarta: Edisi 2007. BPFE.

Haryono, S dan Parwoto W. 2012. Structural Equation Modeling untuk Penelitian Manajemen Menggunakan AMOS 18.00. Bekasi: PT Intermedia Personalia Utama. 
Hasibuan, M. 2006. Manajemen Sumber Daya Manusia Ed. Revisi. Jakarta: Bumi Aksara.

Hasibuan, M. 2009. Manajemen Sumber Daya Manusia (Edisi revisi cetakan ke tiga belas). Jakarta: PT Bumi Aksara

Hasibuan, M. 2014. Model Persamaan Struktural Konsep dan Aplikasi dengan AMOS 22.0, Semarang: Badan Penerbit Universitas Diponegoro.

Hayati, S., Kaukab, M. E., \& Suliyanto, A. Suroso. 2020. The Influence of Interactional Justice, Leader-Member Exchange Quality, Involvement in Job, and Trust to Leader toward Intention to Quit: Case Study in SMEs. International Journal of Advanced Science and Technology Vol. 29, No. 8s, (2020), pp. 3407-3415

Heizer, J\& Barry, R (2011). Manajemen Operasi.Edisi Sembilan. Buku Dua. Diterjemahkan oleh Chriswan Sungkono. Jakarta: Salemba Empat

Husein, U. 2011. Metode Penelitian Untuk Skripsi dan Tesis Bisnis Edisi 11. Jakarta: PT Raja Grafindo Persada

Kaukab, M. E., Adawiyah, W. R., \& Hayati, S. (2020). Islamic Values and Work Ethics on Entrepreneural Performance and its Effects on Intention to Growing Business. International Journal of Psychosocial Rehabilitation, 24(06).

Kuncoro, M. 2003. Metode Riset untuk Bisnis \& Ekonomi. Jakarta: Erlangga.

Kusnendi. 2008. Model-model Persamaan Struktural. Bandung : Alfabeta

Mahsun, M., Sulistyowati dan Heribertus A. P. 2007. Akuntansi sektor publik. Yogyakarta: Edisi Kedua. BPFE.

Mangkunegara, A. 2007. Manajemen Sumber Daya Manusia Perusahaan. Bandung: Remaja Rosdakarya.

Mathis, R.L. \& J.H. Jackson. 2006. Human Resource Management: Manajemen Sumber Daya Manusia. Terjemahan Dian Angelia. Jakarta: Salemba Empat.

Munparidi .2012 . Pengaruh kepemimpinan, motivasi, pelatihan dan lingkungan kerja terhadap kinerja karyawan studi pada perusahaan daerah air minum tirta musi kota palembang. Jurnal Orasi Bisnis Edisi ke-VII, Mei 2012 ISSN: 2085-1375. Jurusan Administrasi Niaga Politeknik Negeri Sriwijaya

Ngakil, I., \& Kaukab, M. E. (2020). Transparansi dan Akuntabilitas Pengelolaan Keuangan Desa di Kabupaten Wonosobo. Journal of Economic, Management, Accounting and Technology (JEMATech), 3(2), 92-107.

Nitisemito, A. 2002. Manajemen Personalia. Cetakan ke 9. Edisi ke 4. Jakarta: Ghalia Indonesia..

Nuraini, T. 2013. Manajemen Sumber Daya Manusia. Yayasan Aini Syam: Pekanbaru.

Potu, A. 2013.Kepemimpinan, Motivasi dan lingkungan kerja pengaruhnya terhadap kinerja karyawan studi pada kanwil ditjen kekayaan negara sulutteggo dan maluku utara di manado. Fakultas Ekonomi dan Bisnis, Jurusan Manajemen Universitas Sam Ratulangi Manado

Prawirosentono, S. Kebijakan Kinerja Karyawan. Yogyakarta: BPFE, 1999 (dalam penelitian Yullyanti, E. 2009. Analisis Proses Rekrutment dan Seleksi pada Kinerja Pegawai. Bisnis \& Birokrasi, Jurnal Ilmu Administrasi Dan Organisasi, Vol. 16, No. 3, Sept- Des 2009, Hlm. 131-139)

Rivai dan basri .2005. Performance Appraisal Sistem yang Tepat untuk menilai Kinerja Karyawan dan meningkatkan Daya saing Perusahaan. Jakarta: Rajagrafindo Persada .

Rivai, V. 2011. Manajemen Sumber Daya Manusia Untuk Perusahaan Dari Teori Ke Praktek. Jakarta: PT. RAJAGRAFINDO PERSADA. 
Rivai, V dan Sagala. 2011. Manajemen Sumber Daya Manusia untuk Perusahaan dari Teori ke Praktik. Jakarta: PT Raja Grafindo.

Robbins, P dan Stephen. (2006). Perilaku Organisasi. Edisi Sepuluh. Diterjemahkan oleh: Drs. Benyamin Molan. Erlangga, Jakarta.

Rozalina, N, dkk. 2015. Pengaruh Motivasi Kerja dan Disiplin Kerja terhadap Kinerja Karyawan studi pada Karyawan PT Pattindo Malang. Fakultas Ilmu Administrasi Universitas Brawijaya Malang

Ruky, A. 2001. Sistem Manajemen Kinerja. Jakarta: PT Gramedia.

Sarwoto. 2007. Dasar-dasar Organisasi Manajemen. Jakarta : Ghalia Indonesia.

Sedarmayanti. 2001. Sumber Daya Manusia dan Produktivitas Kerja. Bandung: Mandar Maju.

Sedarmayanti. 2007. Manajemen Sumber Daya Manusia. Bandung: Penerbit Refika Aditama.

Setiawan, A. 2013. Pengaruh Disiplin Kerja dan Motivasi Kerja terhadap Kinerja Karyawan Studi kasus pada RSUD Kanjuruhan Malang. Jurusan Manajemen, Fakultas Ekonomi, Universitas Negeri Surabaya, Kampus Ketintang Surabaya.

Setiawan, F., \& Kartika Dewi, A. 2014. Pengaruh Kompensasi dan Lingkungan KerjaTerhadap Kinerja Karyawan Pada CV. Berkat Anugrah. Jurnal Manajemen Universitas Udayana, 3(5)

Siagian, S.P.1992. Organisasi Kepemimpinan \& Perilaku Administrasi. Jakarta: Rineka Cipta.

Siagian, S. P.2008. Manajemen Sumber Daya Manusia (Edisi Pertama). Jakarta: Binapura Aksara.

Sidanti, H. 2015. Pengaruh lingkungan kerja disiplin kerja dan motivasi kerja terhadap kinerja PNS disekretariat Dprs kabupaten madiun. Jurnal jibeka Volume 9 Nomor 1 Fbruai 2015: 44-5.Program studi Stie Dharma Iswara Madiun.

Sugiyono. 2005. Memahami Penelitian Kualitatif. Bandung: CV. Alfabeta.

Sugiyono. 2011. Metode Penelitian Bisnis. Cetakan kesembilan. Bandung: PenerbitAlfabeta.

Sugiyono. 2012. Metode Penelitian Pendidikan Pendekatan Kuantitatif, Kualitatif, dan $R \& D$. Bandung: Alfabeta.

Suhartini. 2016. Pengaruh disiplin kerja dan lingkungan kerja terhadap kinerja guru studi pada guru di sd swasta sultan agung di pemantangsiantar. Jurnal MAKER. Program Studi Manajemen.

Suliyanto. 2018. Metode Penelitian Bisnis, Untuk Skripsi,Tesis dan Disertasi. Yogyakarta: Penerbit Andi.

Supardi. 2003. Kinerja Karyawan. Ghalia Jakarta

Sutrisno, E. 2009. Manajemen Sumber Daya Manusia Edisi pertama. Jakarta: Kencana Prenada Media Grup.

Syafrina, N. 2017. Pengaruh Disiplin Kerja terhadap Kinerja Karyawan studi pada PT Suka Fajar Pekanbaru. Sekolah Tinggi Ilmu Ekonomi Riau Jln. HR Subrantas KM 12 .

Taqiya, H. Analisis Semiotika Terhadap Film In The Name Of God (Analisis Semiotika Roland Barthes). Diambil dari http://repository.uinjkt.ac.id/dspace/bitstream/123456789/21832/1/HANI\%20 TAQIYYA-FDK.PDF, pada tanggal 27 September pukul 08.47 wib.

Waryanti, S, D, R. 2011. Analisis pengaruh kecerdasan emosional dan Kecerdasan spiritual terhadap kinerja karyawan(studi empiris pada rumah sakit umum daerah 
kota semarang). Jurnal Fakultas Ekonomika Dan Bisnis Universitas Diponegoro Semarang.

Wijayanto, S. H. (2008). Setructural Ekuation Modeling. Yogyakarta: Graha Ilmu.

Wirawan. 2009. Evaluasi Kinerja Sumber Daya Manusia Teori Aplikasi dan Penelitian. Jakarta. Penerbit: Salemba Empat.

Yulianto, R. 2017. Pengaruh Konflik Peran dan Ambiguitas Peran terhadap Trunover Intensi melalui Stres Kerja sebagai variabel intervening (studi empiris pada karyawan BPJS Kesehatan di Yogyakarta. Yogyakarta. Penerbit: UMY. 